\title{
Examining the Inter-relationships among the Dimensions of Relationship Marketing
}

\author{
Celine Marie Capel \\ University of Nottingham Malaysia, Malaysia \\ Nelson Oly Ndubisi \\ University of Nottingham Malaysia, Malaysia
}

\begin{abstract}
The purpose of this paper is to examine the interrelationship among the dimensions of relationship marketing namely, trust, commitment, communication and conflict handling. Little is understood about the inter-relationship among these factors as all prior efforts in the area have focused on their impact on relationship outcomes such as satisfaction, loyalty and word-of-mouth communication. Some 400 bank customers in Malaysia were surveyed, with 220 usable responses on which analysis was based. The research found that there is strong evidence for the interrelatedness of trust, commitment, communication and conflict handling. Important managerial and marketing implications of the findings are discussed.
\end{abstract}

Keywords: Trust, Commitment, Communication, Conflict handling, Banking, Malaysia

\section{Introduction}

The intense competitive nature of today's business environment among other factors has resulted in the building of long lasting relationships between organizations and customers. Transactional marketing, which has been referred to as a hit and run strategy is increasingly giving way to a more customer centric approach known as relationship marketing. To achieve success in today's complex and competitive market, researchers have prescribed a number of key areas that need to be considered if the customer is to be served satisfactorily. One of these key areas is leveraging firm-customer relationship to gain privileged information about customers and 
thereby better understand their needs. Relationship marketing therefore enables the firm to get closer to its customers in order to correctly sense and serve their expectations in a manner superior to competition.

Marketing studies have documented the following dimensions of relationship marketing namely, trust (Morgan and Hunt, 1994; Ndubisi and Chan, 2005), commitment (Morgan and Hunt, 1994; Ndubisi, 2006; Wong and Sohal, 2002), conflict handling (Ndubisi, 2006), communication or sharing of secrets (Crosby et al., 1990; Morgan and Hunt, 1994). Many have also investigated the impact of these constructs on overall relationship quality, customer satisfaction and customer loyalty. However, investigations of the inter-relatedness of these key relationship marketing variables have been ignored, even though such studies are necessary for understanding how these factors support one another as antecedents of customer satisfaction and customer loyalty, the goals of most organisations.

The aims of this study are twofold. The first is to better understand the murky area of the interrelationship or interconnectivity of the key dimensions of relationship marketing. Due to dearth of research in this area, there is a very poor understanding of how these factors interplay. So far, works in this area have tried to link selected RM dimensions to higher order constructs such as relationship quality, customer satisfaction and customer loyalty, ignoring the possible relationships among these dimensions. The understanding gained by testing such inter-relationships will show how one dimension (or virtue) can grow by growing others. The second impetus for the study is to unveil the actual influences of the RM constructs on customer loyalty. Although there are few existing studies focusing on this relationship, the contextual nature and the mixed findings of these efforts created a need for the Malaysian perspective to be documented. As mentioned earlier, Malaysia has graduated to become an important unit of the world economy that cannot be ignored today because of its impact on the global economic system. The outcome of this research holds significant benefits for marketing researchers and practitioners, as well as banks (and other service organizations by extension) who are interested in the subjects of customer relationship management and customer loyalty.

\section{Literature Review}

Interest in the economics of long-lasting customer relationship has been growing since the last few decades. Some of the motives for organizational investment in building relationship with customers include, access to privileged information on customers' needs and wants (Ndubisi, 2004), mutual rewards (Rapp and Collins, 1990), cost reduction and increase in profitability (Ndubisi, 2004). Reichheld (1993) reported that a 5 percent increase in customer retention grew the company's profit by 60 percent by the fifth year. It has been argued that long-term relationships where both parties over time learn how best to interact with each other lead to decreasing relationship costs for the customer as well as for the supplier or service provider. 
Relationship marketing has been defined as a strategy to attract, maintain and enhance customer relationships (Berry, 1983). It was argued that the goals of relationship marketing are to create and maintain lasting relationships between the firm and its customers that are rewarding for both sides (Rapp and Collins, 1990). Gronroos (1994) reasoned that relationship marketing is to establish, maintain, and enhance relationships with customers and other partners, at a profit, so that the objectives of the parties involved are met This is achieved by a mutual symbiosis and fulfillment of promises (Ndubisi, 2004). Gummesson (1993) concluded that relationship marketing is a strategy where the management of interactions, relationships and networks are fundamental issues. The interaction and network approach of industrial marketing and modern service marketing approaches, clearly views marketing as an interactive process in a social context where relationship building and management are a vital underpinning (Bagozzi, 1975; Webster, 1992). Kotler (1992) prescribed that companies must move from short-term transaction-oriented goal to long-term relationship-building goal. In an analysis of the current developments in business and in marketing, Webster (1992, p. 14) reported that "there has been a shift from a transaction to a relationship focus."

Kavali et al. (1999) indicated that relationship marketing is about healthy relationships characterized by trust, equity, and commitment. Key virtues that have been conceptualized in the relationship marketing literature include trust (Morgan and Hunt, 1994; Ndubisi and Chan, 2005), commitment (Morgan and Hunt, 1994; Wong and Sohal, 2002), conflict handling (Ndubisi, 2006), and communication (Crosby et al., 1990). This study conceptualizes that these concepts are interrelated (Figures 14).

Figure 1 Predictors of Trust (Model 1)

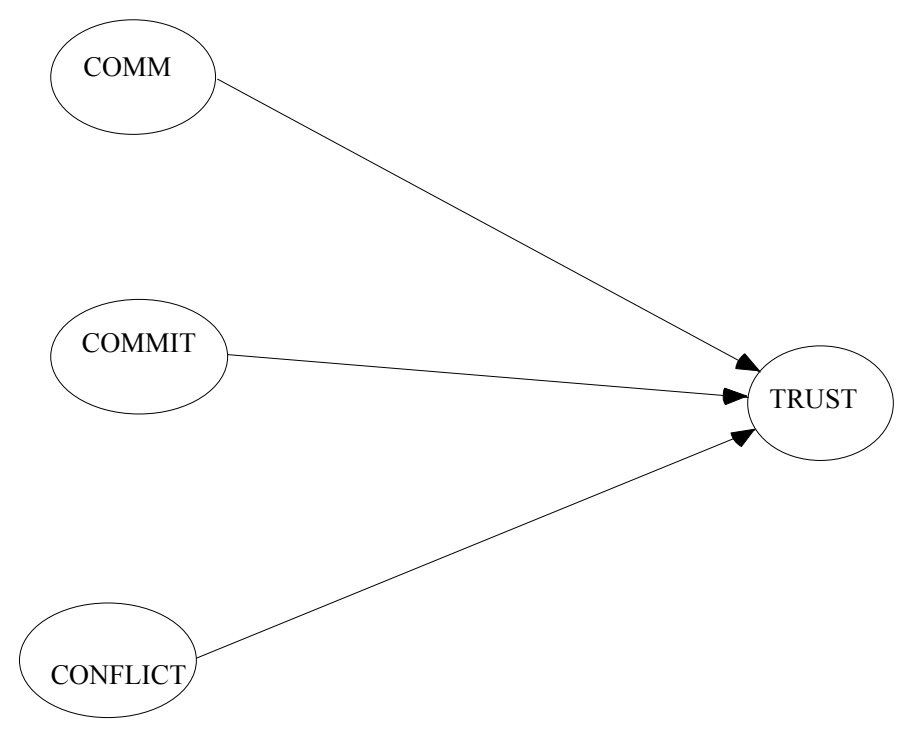


Figure 2 Predictors of Commitment (Model 2)

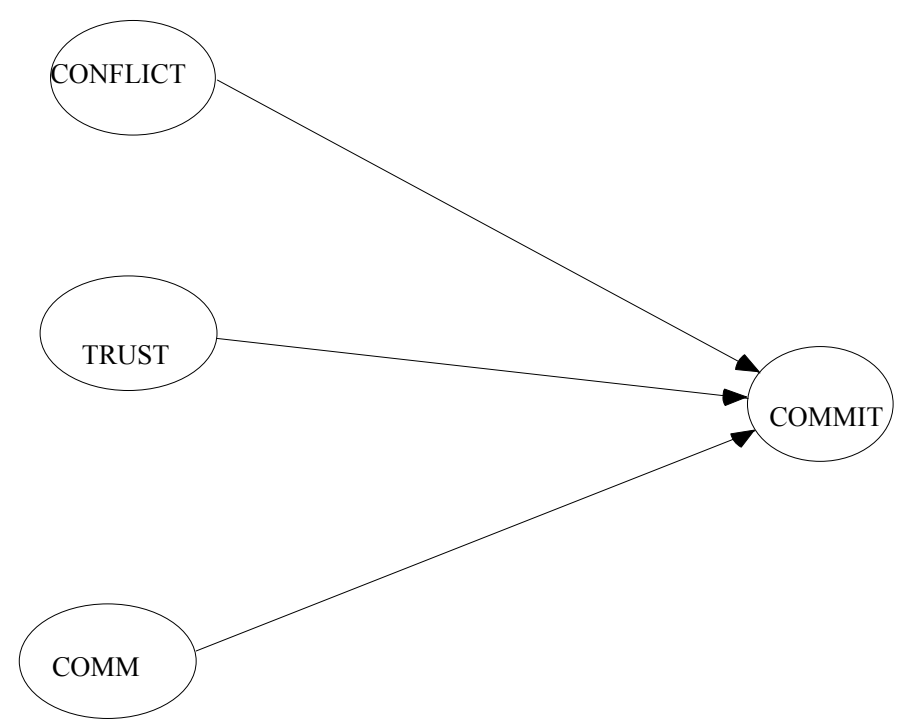

Figure 3 Predictors of Communication (Model 3)

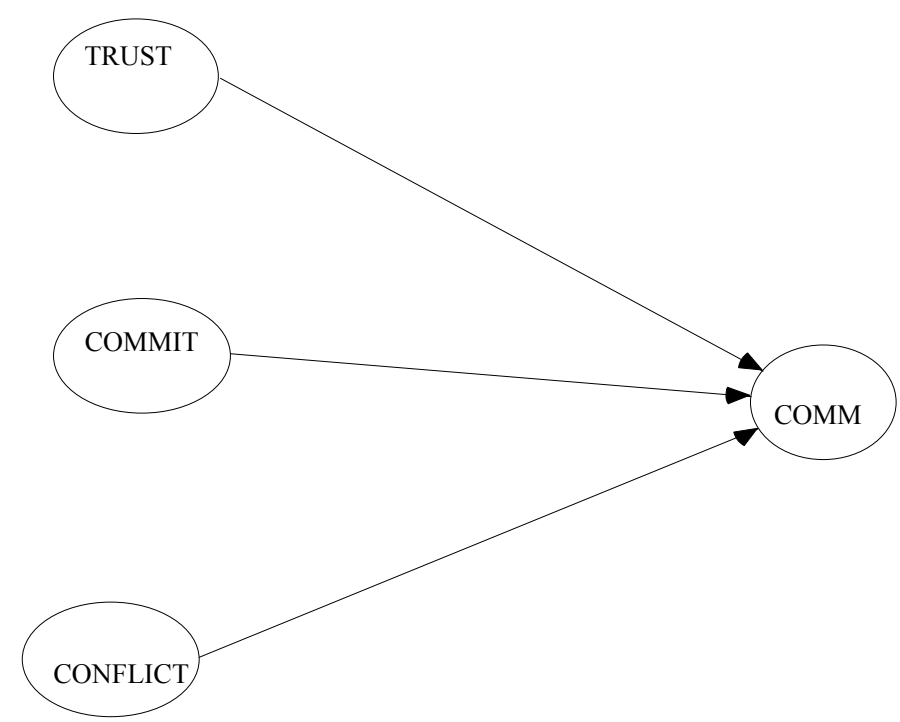


Figure 4 Predictors of Conflict Handling (Model 4)

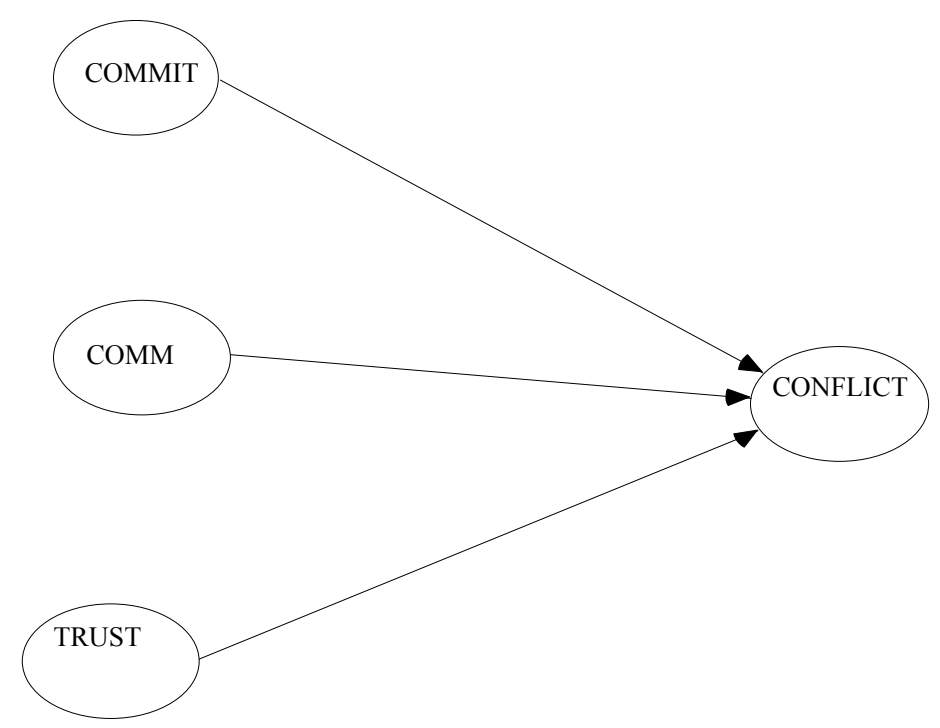

Trust and its role in fostering firm-customer relationship quality and customer satisfaction have been studied significantly. However, relatively little attention has gone into the investigation of its impact on customer loyalty. Abratt and Russell (1999) remarked that partners in a relationship need to have trust and good intentions among themselves. Schurr and Ozanne (1985) defined trust as the belief that a partner's word or promise is reliable and a party will fulfill his/her obligations in the relationship. Moorman et al. (1993) defined the term as ".... a willingness to rely on an exchange partner in whom one has confidence. Other scholars have defined trust in terms of opportunistic behavior (Dwyer et al., 1987), shared values (Morgan and Hunt, 1994), mutual goals (Wilson, 1995), making and keeping promises (Bitner 1995), uncertainty (Crosby et al., 1990), and actions with positive outcomes (Anderson and Narus, 1984). A betrayal of this trust (by the supplier or service provider) can lead to customer dissatisfaction and defection. Gronroos (1990) asserted that the resources of the seller - personnel, technology and systems - have to be used in such a manner that the customer's trust in the resources involved and, thus, in the firm itself, is maintained and strengthened. Indeed, one would expect a positive outcome from a partner on whose integrity one can rely on confidently (Morgan and Hunt, 1994). Pearce (1974) differentiated this trust (i.e. cognitive trust - the subjective probability that the other will behave trustworthily) from trusting behavior. According to Pearce, it would be possible for a person to engage in trusting behavior without having reached "a cognitive state of trust". Trust is expected to lead to customer loyalty. 
Commitment is one of the important variables for understanding the strength of a marketing relationship, and it is a useful construct for measuring the likelihood of customer loyalty as well as for predicting future purchase frequency (Dwyer et al., 1987; Gundlach et al., 1995; Morgan and Hunt, 1994). Wilson (1995) argued that commitment is the most common dependent variable used in buyer-seller relationship studies. In sociology, the concept of commitment is used to analyze both individual and organizational behavior (Becker, 1960). Sociologists use commitment as a descriptive concept to mark out forms of action characteristic of particular kinds of people or groups (Wong and Sohal, 2002), while psychologists define commitment in terms of decisions or cognitions that fix or bind an individual to a behavioral disposition (Kiesler, 1971). In marketing, Moorman et al. (1992) defined commitment as an enduring desire to maintain a valued relationship. This implies a higher level of obligation to make a relationship succeed and to make it mutually satisfying and beneficial (Gundlach et al., 1995; Morgan and Hunt, 1994). Since commitment is higher among individuals who believe that they receive more value from a relationship, highly committed customers should be willing to reciprocate effort on behalf of a firm due to past benefits received (Mowday et al., 1982) and highly committed firms will continue to enjoy the benefits of such reciprocity.

Communication refers to the ability to provide timely and trustworthy information. Communications is now viewed as an interactive dialogue between the company and its customers that takes place during the pre-selling, selling, consuming and postconsuming stages (Anderson and Narus, 1990). Communication in relationship marketing includes providing information that can be trusted; providing timely information, and providing information when problem occurs. It is the role of communication to build awareness, build consumer preference by promoting quality, value, performance and other features, convince and encourage customers to make the purchase decision and to nurture quality customer relationship. Communication also tells a customer who is dissatisfied what the organization is doing to rectify the source of dissatisfaction. Berry (1995) remarked that buyer-seller interactions must be open, sincere and frequent because improving the quality of the relationship will encourage customer retention. Open, sincere and frequent interactions describe effective communication. When there is effective communication between the bank and the customers, customers are likely to be more loyal.

Dwyer et al. (1987) defined conflict handling as the supplier's ability to minimize the negative consequences of manifest and potential conflicts. Conflicts handling reflects the supplier's ability to avoid potential conflicts, solve manifest conflicts before they create problems and the ability to discuss openly solutions when problems arise. How conflicts are handled will ensure loyalty, exit or voice. Rusbult et al. (1988) concluded that the likelihood that an individual will engage in these behaviors depends on the degree of prior satisfaction with the relationship, the magnitude of the person's investment in the relationship and an evaluation of the alternatives one has. The ability of the bank to handle conflict well will impact customer loyalty. To handle conflicts efficiently, there must be open, sincere and frequent interaction (Berry, 1995) until acceptable, satisfactory resolution is reached.

The above discussion leads to the following five main hypotheses: 
H1: There is a significant relationship between (a) commitment, (b) communication, (c) conflict handling and trust.

H2: There is a significant relationship between (a) trust, (b) communication, (c) conflict handling and commitment.

H3: There is a significant relationship between (a) trust, (b) commitment, (c) conflict handling and communication.

H4: There is a significant relationship between (a) trust, (b) commitment, (c) communication and conflict handling.

\section{Methodology}

The population for this study is the retail bank customers in Sabah, Malaysia. Sabah known in many Western circles as the Malaysia Borneo is an upcoming geographical location in the Eastern part of Malaysia. Although it is fast becoming a banking hub, very little research attention has been given to it relative to the Peninsular Malaysia. The choice of banking industry was made for two key reasons: (1) Although the concept of relationship marketing has emerged within the field of service marketing (Berry, 1983; Christopher et al., 1991; Gummesson, 1991; Jackson, 1985; Lindgreen et al., 2004), research in the field remains inconclusive as past studies reported differing results; (2) Banking is a volitional service with very low switching cost in Malaysia (Ndubisi and Tam, 2007). By choosing a low switching cost industry, we ensure that customers are not under forced loyalty (i.e. they are not retained because of lack of choice) and they could exit if and when they wish to. The participating banks were drawn from the Malaysian Banking Institute. A total of 400 customers voluntarily accepted the survey forms which were personally administered outside the bank's premises. Of this number, 230 completed and returned the instrument. This is a $57.5 \%$ response rate. Out of this only 220 were usable as 10 were voided because of incomplete data.

Malaysian banks are highly regulated by the Central Bank and are known for their highly standardized services, which allows for aggregation of the samples. A recent study showed that switching costs among commercial banks in Malaysia were insignificant (Ndubisi and Tam, 2007). The authors demonstrated that the close proximity of these banks, uniform offerings, similarity of interest charges, among others contributed to the insignificant switching costs. Nevertheless, because certain banks can have specific characteristics, which might influence the forces driving relationship quality, we statistically tested for any differences that may potentially confound the results. To examine these differences one-way analysis of variance (ANOVA) was used similar to the procedure adopted by Veloutsou et al. (2004). To identify which bank customers have different perceptions, the Duncan test was used. This was re-confirmed using the Scheffe test and both reveal no statistical differences. Details of the ANOVA results show no statistical differences among the various banks with respect to the relationship marketing dimensions namely, trust $(\mathrm{F}=.799$; sig. 
$=.670)$, commitment $(\mathrm{F}=.815 ;$ sig. $=.652)$, communication $(\mathrm{F}=.850 ;$ sig. $=.614)$ and conflict handling $(\mathrm{F}=.517$; sig. $=.922)$, and overall relationship quality $(\mathrm{F}$ $=.597$; sig. $=.865)$, hence the data can be pooled without hiding any confounding effect or loosing any important information.

The questionnaire items were adapted from different sources and summarized in Table 1. Communication, commitment and conflict handling items were adapted from Morgan and Hunt (1994) and Ndubisi (2006). Communication had 5 items, commitment included 4 items, and conflict handling had 3 items. Items for trust were adapted from Churchill and Surprenant (1982) and Ndubisi (2006). Trust had six items. The Multiple Regression Model was employed to predict the relationships in the construct. In view of the relatively small sample $(n=220)$ used in this study, regression analysis would be helpful (Bollen, 1989) since the statistical test of chi square in structural equations model is sensitive to sample size. The following assumptions of regression analysis were tested to ascertain non-violation before accepting the results: (1) linearity of the relationship, (2) constant variance of the error terms (homoscedasticity), (3) independence of the error terms (no autocorrelation), and (4) normality of the error term distribution.

\section{Table 1 Items and Sources}

\begin{tabular}{|c|c|c|}
\hline Variables & Items Summary & Sources \\
\hline Trust & $\begin{array}{l}\text { Bank's concern for security of transactions. } \\
\text { Bank's promises are reliable. } \\
\text { Bank fulfils obligation to customer. } \\
\text { Bank provides quality service. } \\
\text { Employees show respect to customers. } \\
\text { Customers have confidence in the bank's } \\
\text { services. }\end{array}$ & $\begin{array}{l}\text { Churchill and } \\
\text { Surprenant, 1982; } \\
\text { Ndubisi, } 2006 .\end{array}$ \\
\hline Commitment & $\begin{array}{l}\text { Bank offers personalize services. } \\
\text { Bank's flexibility in serving customer needs. } \\
\text { Bank's flexibility when services are changed. } \\
\text { Making adjustments to suit customers' needs. }\end{array}$ & \multirow[t]{3}{*}{$\begin{array}{l}\text { Morgan and Hunt, } \\
\text { 1994; Ndubisi, } \\
2006 .\end{array}$} \\
\hline Communication & $\begin{array}{l}\text { Bank provides timely information. } \\
\text { Bank provides trustworthy information. Bank } \\
\text { provides information if problem occurs. } \\
\text { Bank provides information when there are new } \\
\text { banking services. } \\
\text { Bank gives and promises. }\end{array}$ & \\
\hline Conflict Handling & $\begin{array}{l}\text { Bank avoids potential conflicts. } \\
\text { Bank manifest conflicts before they create } \\
\text { problems. } \\
\text { Bank and openly discusses problems. }\end{array}$ & \\
\hline
\end{tabular}




\section{Results and Discussion}

\section{Respondents' Characteristics}

Table 2 is the summary of the demographic composition of the respondents. No statistical differences were observed in the mean values of the dimensions of interest based on the demographics of the respondents.

Table 2 Respondents’ Demographic Profile

\begin{tabular}{|c|c|c|c|c|}
\hline No & Profile & Description & Responses & Percentage \\
\hline \multirow[t]{4}{*}{1} & \multirow[t]{4}{*}{ Age } & Below 20 years & 7 & 3.2 \\
\hline & & $20-39$ years & 161 & 73.2 \\
\hline & & $40-59$ years & 50 & 22.7 \\
\hline & & 60 years above & 2 & 0.9 \\
\hline \multirow[t]{2}{*}{2} & \multirow[t]{2}{*}{ Gender } & Male & 92 & 41.8 \\
\hline & & Female & 128 & 58.2 \\
\hline \multirow[t]{3}{*}{3} & \multirow[t]{3}{*}{ Occupation } & Business & 11 & 5.0 \\
\hline & & Student/Housewife/Retiree & 17 & 7.7 \\
\hline & & Paid Employment & 192 & 87.3 \\
\hline \multirow[t]{4}{*}{4} & \multirow{4}{*}{$\begin{array}{l}\text { Monthly } \\
\text { Income }\end{array}$} & Below RM2000 & 90 & 40.9 \\
\hline & & RM2000 - RM3999 & 97 & 44.1 \\
\hline & & RM4000 - RM5999 & 22 & 10.0 \\
\hline & & RM6000 and above & 11 & 5.0 \\
\hline \multirow[t]{5}{*}{5} & \multirow{5}{*}{$\begin{array}{l}\text { Highest } \\
\text { Educational } \\
\text { Qualification }\end{array}$} & Primary & 5 & 2.3 \\
\hline & & Secondary & 47 & 21.4 \\
\hline & & HSC/Diploma & 73 & 33.2 \\
\hline & & Degree & 82 & 37.3 \\
\hline & & Postgraduate & 13 & 5.9 \\
\hline
\end{tabular}

Apart from the descriptive statistics in the table above, information on the respondents' relationship with the bank, based on the number of years they have been with the particular bank show that $19 \%$ had been with the bank for 5 years or less, $39 \%$ between $6-10$ years and $42 \%$ had been with the bank for 11 years or more. These results show that respondents have a considerable level of repurchase behaviour towards their bank.

\section{Psychometric Properties}

Confirmatory factor analysis was used to test the measurement properties (Table 3). The oblique factor rotation was employed for this analysis, since the factors are conceptually linked, and oblique rotation represents the clustering of variables more accurately (Hair et al., 1998) as compared to the orthogonal rotation, which keeps factors uncorrelated throughout the rotation process. Convergent validity is established if all item loadings are equal to or above the recommended cut-off level of 
0.60 (Chin et al., 1997). An alternative is parsimonious sets of variables, guided by conceptual and practical considerations, namely acceptance of factor loadings of 0.50 and above (Hair et al., 1998). Based on Hair and colleagues (1998), all items in the study have a loading higher than the recommended threshold. Thus, overall we believe that a reasonable degree of convergent validity was established. High communality values are recorded for all the variables, indicating that the total amount of variance an original variable shares with all other variables included in the analysis is high. A total of 17 items loaded on 5 dimensions with total variance of 64 percent.

Table 3 Key Dimensions, Items, and Communalities

\begin{tabular}{|c|c|c|c|c|c|}
\hline \multirow[t]{2}{*}{ Items } & \multicolumn{4}{|c|}{ Loadings and Cross Loadings } & \multirow[t]{2}{*}{ Communalities } \\
\hline & F1 & $\mathrm{F} 2$ & F3 & $\mathrm{F} 4$ & \\
\hline $\begin{array}{l}\text { 1. The bank is concerned about } \\
\text { the security of my transactions. } \\
\text { 2. The bank's promises are } \\
\text { reliable. }\end{array}$ & .60 & -.073 & .261 & -.093 & 0.54 \\
\hline $\begin{array}{l}\text { 3. The bank fulfils obligations to } \\
\text { customers. }\end{array}$ & .63 & .043 & .225 & .158 & 0.60 \\
\hline $\begin{array}{l}\text { 4. The bank consistently provides } \\
\text { quality services. }\end{array}$ & .78 & -.048 & -.147 & .090 & 0.63 \\
\hline $\begin{array}{l}\text { 5. Employees show respect to } \\
\text { customers. }\end{array}$ & .70 & .072 & .185 & .026 & 0.56 \\
\hline $\begin{array}{l}\text { 6. I have confidence in the bank's } \\
\text { services. (Eigenvalue }=6.564 \text {; } \\
\text { Variance }=38.61 \% \text {; Cronbach's }\end{array}$ & .75 & -.033 & -.212 & .067 & 0.56 \\
\hline Alpha $=0.84)$ & .75 & -.035 & .178 & -.178 & 0.65 \\
\hline $\begin{array}{l}\text { 7. The bank offers personalize } \\
\text { services. }\end{array}$ & .015 & -.83 & .074 & .025 & 0.76 \\
\hline $\begin{array}{l}\text { 8. The bank is flexible in serving } \\
\text { customer needs. }\end{array}$ & .026 & -.60 & .061 & .304 & 0.62 \\
\hline $\begin{array}{l}\text { 9. The bank is flexible when } \\
\text { services are changed. }\end{array}$ & -.081 & -.80 & .049 & .171 & 0.72 \\
\hline $\begin{array}{l}\text { 10. The bank makes adjustments } \\
\text { to suit customers' needs. } \\
\text { (Eigenvalue }=1.630 ; \text { Variance }= \\
9.59 \% \text {; Cronbach's Alpha }=0.84 \text { ) }\end{array}$ & .051 & -.86 & .024 & -.226 & 0.71 \\
\hline $\begin{array}{l}\text { 11. The bank provides timely } \\
\text { information. }\end{array}$ & .127 & .084 & .75 & -.098 & 0.63 \\
\hline $\begin{array}{l}\text { 12. The bank provides accurate } \\
\text { information. }\end{array}$ & .164 & -.190 & .61 & -.088 & 0.60 \\
\hline $\begin{array}{l}\text { 13. The bank makes and fills } \\
\text { promises. }\end{array}$ & .076 & -.273 & .60 & .097 & 0.60 \\
\hline $\begin{array}{l}\text { 14. The bank provides } \\
\text { information when there are new } \\
\text { banking services. } \\
(\text { Eigenvalue }=1.538 ; \text { Variance }= \\
9.05 \% \text {; Cronbach's Alpha }=0.78 \text { ) }\end{array}$ & -.046 & -.102 & .78 & .065 & 0.66 \\
\hline $\begin{array}{l}\text { 15. The bank tries to avoid } \\
\text { potential conflicts. } \\
\text { 16. The bank tries to solve }\end{array}$ & -.076 & .066 & .321 & .83 & 0.78 \\
\hline
\end{tabular}




\begin{tabular}{|c|c|c|c|c|c|}
\hline Items & Load & s and $C$ & oss Loa & ings & \begin{tabular}{|l} 
Commulities \\
\end{tabular} \\
\hline $\begin{array}{l}\text { manifest conflicts before they } \\
\text { create problems. } \\
\text { 17. The bank openly discusses } \\
\text { problems when they arise. } \\
(\text { Eigenvalue }=1.064 ; \text { Variance }= \\
6.26 \% \text {; Cronbach's Alpha }=0.73 \text { ) }\end{array}$ & .287 & -.210 & -.149 & .60 & 0.64 \\
\hline
\end{tabular}

F1 - Trust; F2 - Commitment; F3 - Communication; F4 - Conflict Handling;

Total Variance $=64 \% ; \mathrm{KMO}=.880 ;$ Chi-Square $=1629.17 ; \mathrm{df}=136.00 ; \mathrm{Sig}=.000$

The internal consistency of the instrument was tested via reliability analysis. Reliability estimates (Cronbach's Alpha) for the construct's dimensions are as follows: Trust (0.84), Communication (0.78), Commitment (0.84), and Conflict Handling (0.73), suggesting a high degree of reliability. The results very well exceed the 0.60 (Hair et al. 1998) lower limit of acceptability. The means (with standard deviation) of the construct dimensions are considered high based on the following statistics: trust $(3.95 ; 0.53)$, commitment $(3.67 ; 0.73)$, communication $(3.90 ; 0.62)$, and conflict handling $(3.73 ; 0.64)$.

\section{Inter-relationships amongst the RM Dimensions}

To examine the influences of the RM dimensions on one another, regression analyses were conducted. The results in Table 4 show both the significant and non-significant beta coefficients and the level of significance of the associations.

Table 4 Inter-relationships among RM Dimensions

\begin{tabular}{|c|c|c|c|c|}
\hline \multirow{2}{*}{$\begin{array}{l}\text { Predictor } \\
\text { Variables } \\
\end{array}$} & \multicolumn{4}{|c|}{ Dependent Variables with Beta Coefficient } \\
\hline & Trust & Commitment & Communication & $\begin{array}{l}\text { Conflict } \\
\text { Handling }\end{array}$ \\
\hline Trust & N/a & $.138^{*}$ & $.419^{* *}$ & $.329 * *$ \\
\hline Commitment & $.147^{*}$ & $\mathrm{~N} / \mathrm{a}$ & $.317 * *$ & $.388^{* *}$ \\
\hline Communication & $.342 * *$ & $.286 * *$ & $\mathrm{~N} / \mathrm{a}$ & .038 \\
\hline \multirow[t]{2}{*}{$\begin{array}{l}\text { Conflict } \\
\text { Handling }\end{array}$} & $.319^{* *}$ & $.343^{* *}$ & .045 & $\mathrm{~N} / \mathrm{a}$ \\
\hline & $\begin{array}{l}\mathrm{R} 2=.429 \\
\mathrm{~F}=53.79 \\
\text { Sig. F. }=.000\end{array}$ & $\begin{array}{l}\mathrm{R} 2=.389 \\
\mathrm{~F}=45.82 \\
\text { Sig. F. }=.000\end{array}$ & $\begin{array}{l}\mathrm{R} 2=.435 \\
\mathrm{~F}=54.41 \\
\text { Sig. F. }=.000\end{array}$ & $\begin{array}{l}\mathrm{R} 2=.408 \\
\mathrm{~F}=49.09 \\
\text { Sig. F. }=.000\end{array}$ \\
\hline
\end{tabular}

N/a - Not applicable, $* p<.05, * * p<.001$ 
From Table 5 above, it is observed that commitment, communication, and conflict handling contribute significantly $(\mathrm{F}=53.79 ; p<0.001)$ and predict $43 \%$ of the variations in trust. In other words, these dimensions predict a significant change in customer trust. It is further observed that the three dimensions are significantly associated with trust at the 5\% significance level. This result validates hypotheses $1 \mathrm{a}$, $1 \mathrm{~b}$ and $1 \mathrm{c}$. Therefore, the level of trust customers have on the bank depends on the level of commitment of the bank, communication efficiency, and the conflict handling ability of the bank.

Similarly, trust, communication, and conflict handling contribute significantly $(\mathrm{F}=$ $45.82 ; p<0.001)$ and predict $39 \%$ of the variations in perceived commitment. These dimensions predict a significant change in perceived bank's commitment. At the $5 \%$ significance level, the three dimensions are significantly associated with commitment. Hence, customers' perception of the bank's commitment is influenced by the latter's trustworthiness, communication efficiency, and conflict handling ability. Hypotheses $2 \mathrm{a}-2 \mathrm{c}$ are supported the results.

Next, the influences on communication were examined. It was found that trust, commitment, and conflict handling contribute significantly $(\mathrm{F}=54.41 ; p<0.001)$ and predict $44 \%$ of the variation in the perceived efficiency of the banks' communications. It was further revealed that only trust and commitment are the significant factors; conflict handling is not, hence hypotheses $3 \mathrm{a}$ and $3 \mathrm{~b}$ are accepted and $3 \mathrm{c}$ is rejected.

Lastly, trust, commitment, and communication contribute significantly $(\mathrm{F}=49.09 ; p<$ 0.001 ) and predict $41 \%$ of the variations in conflict handling. However, only trust and commitment are significantly associated with conflict handling ( $\mathrm{H} 4 \mathrm{a}$ and $\mathrm{H} 4 \mathrm{~b}$ ); communication is not a significant factor $(\mathrm{H} 4 \mathrm{c})$. Thus, trusted and committed banks are deemed able to handle or resolve conflicts well.

\section{Confirmatory Relationship Tests}

It is important to further examine the robustness of these relationships by comparing the impacts of differing levels of the RM dimensions on one another. For these tests, different levels of trust, commitment, communication and conflict handling were categorized. Categorization of these dimensions followed the method used by Moschis and Moore (1979) and Carlson et al. (1990). The scales were summed and customers classified as low or high on each dimension by splitting at the median. The median of each dimension is as follows: trust (4.00), commitment (3.75), communication (4.00), and conflict handling (3.67). Below the median is low level, and above the median is high level. Dummy variables were created before using the two categories in the regression analysis. In creating the dummy variables, the first step was to decide on the number of dummy variables, which is simply $\mathrm{k}-1$, where $\mathrm{k}$ is the number of levels of the original variable. In this instance $2-1=1$ dummy variable was created as follows: low level $=0$ (un-coded variable) $\&$ high level $=1$ 
(coded variable). For all dependent dimensions, metric data were used (not the recoded categories). The results of the analyses are presented next.

The results presented in Table 5 show that the coded variables (higher level) more significantly determine the dependent variable than the un-coded variable (lower level).

Table 5 Inter-relationships among Levels of RM Dimensions

\begin{tabular}{|c|c|c|c|c|}
\hline \multirow[t]{2}{*}{ Predictor Variables } & \multicolumn{4}{|c|}{ Dependent Variables with Beta Coefficient } \\
\hline & Trust & Commitment & Communication & $\begin{array}{l}\text { Conflict } \\
\text { Handling }\end{array}$ \\
\hline Dummy Trust & $\mathrm{N} / \mathrm{a}$ & $.182 *$ & $.430 * *$ & $.323 * *$ \\
\hline Dummy Commitment & $.125^{*}$ & $\mathrm{~N} / \mathrm{a}$ & $.246 * *$ & $.318^{* *}$ \\
\hline $\begin{array}{l}\text { Dummy } \\
\text { Communication }\end{array}$ & $.419 * *$ & $.248 * *$ & N/a & .078 \\
\hline \multirow{2}{*}{$\begin{array}{l}\text { Dummy Conflict } \\
\text { Handling }\end{array}$} & $.231 * *$ & $.269 * *$ & .074 & $\mathrm{~N} / \mathrm{a}$ \\
\hline & $\begin{array}{l}\mathrm{R} 2=.326 \\
\mathrm{~F}=34.26 \\
\text { Sig. F. }= \\
.000\end{array}$ & $\begin{array}{l}\mathrm{R} 2=.263 \\
\mathrm{~F}=25.58 \\
\text { Sig. F. }=.000\end{array}$ & $\begin{array}{l}\mathrm{R} 2=.327 \\
\mathrm{~F}=34.71 \\
\text { Sig. F. }=.000\end{array}$ & $\begin{array}{l}\mathrm{R} 2=.302 \\
\mathrm{~F}=31.12 \\
\text { Sig. F. }=.000\end{array}$ \\
\hline
\end{tabular}

Dummy definition: Low (un-coded variable); High (coded variable).

Interestingly, the results in Table 5 buttress the findings in Table 4 to a very great extent. The outcome of this test consistently shows that higher level of the predictor dimensions is more robust than the lower level in determining the dependent dimensions. The following inferences are therefore drawn from the outcome of the above results. First, customers with greater perception of the bank's commitment to service, reliability and efficiency of communications, and conflict handling ability, tend to trust the bank more than customers with a lower level of these impressions. Second, customers with greater perception of the bank's trustworthiness, communication efficiency and reliability, and conflict handling ability, deem the bank to be committed to service compared to customers with a lower level of perceptions. Third, customers with greater perception of the bank's trustworthiness, and commitment to service, tend to see the bank as a reliable and efficient communicator more than customers with a lower level of acuity. Last, customers with greater perception of the bank's trustworthiness, and commitment to service, deem the bank more able to handle conflict than do customers with a lower level of the impressions. 


\section{Implications and Conclusions}

The implication of this study on theory is mainly in establishing the interconnectivity among the relationship marketing variables. The outcome of the study demonstrates the inter-relatedness of these variables. Using Malaysia as a research setting, this research found that trust is enhanced through commitment, communication, and better conflict handling. Perceived commitment is improved through communication, trust, and better conflict handling; and so on. The unveiling of the strong inter-relationships among the relationship marketing dimensions adds value to the body of knowledge in the field. The results provide empirical support for, and build on some of the past efforts in this area. Past research in this area (e.g. Morgan and Hunt, 1994; Ndubisi, $2006,2007)$ had concentrated on the effects of relational dimensions on relational outcomes such as satisfaction, loyalty, word-of-mouth communication, and overall relationship quality; no known attention had gone into exploring the inter-linkages of these relationship constructs. As such, this study adds significant value to extant literature in the areas of relationship marketing, relational dynamics and services marketing.

This research has a number of implications on customer management by banks. Firstly, banks in particular and service organizations in general, which have keen interest in acquiring and keeping valuable customers, should try to build quality relationship with them. To build quality relationships, banks should act trust-worthily. They must give and keep promises, be concerned about the security of transactions, provide quality services, show respect to customers, fulfill obligations to customers, and continuously strive to enhance customers' confidence in the bank. These actions will lead to increased trust in the bank and its services. Commitment is another important factor for developing quality relationship. This includes commitment to service and customer relationship. Commitment requires the bank to make adjustments to customers' needs; to tailor-make products to customers' requirements; to be flexible when products are changed, and when the production process is changed. Reliable and efficient communication with customers is inevitably a factor that will make customers perceive quality in the bank-customer interactions. By providing timely and trustworthy information, providing information if problem occurs, providing information on new banking services, providing accurate information and so on, the bank will be seen as a good communicator, and will be appreciated by the customers. Lastly conflict handling is another important factor. Since there is no guarantee that something may not go wrong in the course of the interactions between the bank and its customers, it becomes important that the bank puts in place effective conflict resolution mechanisms. They should also try to avoid potential conflicts and openly discuss problems with customers.

Since trust, commitment, communication, and conflict handling are indicators of relationship quality, which are inter-related, it becomes necessary and rewarding that organizations nurture these virtues. To enhance customers trust in the organization, management and staff of Malaysian banks besides the suggestions made earlier in the preceding paragraph, should strive to achieve high level of commitment to service and customer relationship, always communicate timely and reliable information, and endeavor to resolve conflicts satisfactorily before they create more problems. They 
can improve customers' perceptions of their commitment by willingly communicating timely and reliable information, resolving conflicts decisively and satisfactorily without unreasonable losses to customers, and behaving trustworthily. Lastly, in order to be seen as excellent conflict managers, banking services providers should build trust and show commitment to the needs of customers by adopting proactive approaches and strategies. They should approach conflicts and handle them well by identifying sources of potential conflicts and forestall them before they occur.

In conclusion, this research has investigated the inter-relationship, of relationship marketing dimensions namely, trust, communication, commitment, and conflict handling. By using the data supplied by bank customers in Malaysia, some important findings were unveiled. The study found that building quality relationship with customers calls trust, commitment, communication and conflict handling. Hence, banking service providers interested in improved relationship quality should build trust, commitment, communication, and conflict handling. There is strong evidence for the inter-relationships among the RM dimensions. These findings are beneficial to researchers and practitioners interested in the subject of relationship marketing and relational dynamics.

\section{Future Research Directions}

Future research should test these relationships in other service sectors other than banking, for example, tourism, hospitality, health care and education. A study of this nature that compares different service sectors will help to understand the effects (if any) of industry/sector characteristics and industry/sector culture (Markoczy, 2000; Hodgkinson and Johnson, 1994). By controlling for these potential confounding effects, more generalizable outcomes can emerge.

Future research can also test these inter-relationships in different cultures. Hofstede (1980), Hofstede and Bond (1988) and Hofstede (1991) suggested that culture can be characterized according to five dimensions: individualism-collectivism, power distance, uncertainty avoidance, masculinity-femininity, and long term orientation. Although these dimensions have often been criticized in management and psychology for being overly simplistic (Osland and Byrd, 2000), the conceptual parsimony provided by these dimensions and the broad range of applicability across different countries and cultures provide an adequate starting place for understanding cultural differences, particularly in marketing relationships and relationship outcomes.

Moreover, future research in this area can introduce some other (less researched) relational dynamics such as empathy, competence, respect, rapport, power, and cooperation. By examining these effects, this future study will add value to the present knowledge in this area, by pushing back the frontier of knowledge in the field. 


\section{References}

Abratt, R. and Russell, J. (1999), "Relationship marketing in private banking in South Africa", International Journal of Bank Marketing, vol. 17, no. 1, pp. 5-19.

Anderson, J.C. and Narus, J.A. (1984), "A model of the distributor's perspective of distributor-manufacturer working relationship", Journal of Marketing, vol. 48, no. pp. 62-74.

Anderson, J.C., and Narus, J.A. (1990), "A model of distributor firm and working partnerships", Journal of Marketing, vol. 54, no. 1, pp. 42-58.

Bagozzi, R. (1975), “Marketing as exchange”, Journal of Marketing, vol. 39, no. 4, pp. 32-39.

Becker, H.S. (1960), "Notes on the concept of commitment", American Journal of Sociology, vol. 66 , no. 1, pp. 32-40.

Berry, L.L. (1983), "Relationship marketing” in Berry, L.L., Shostack, G.L. and Upah, G.D. (Eds.), Emerging Perspectives of Services Marketing, Chicago, IL: American Marketing Association, pp. 25-28.

Berry, L.L. (1995), "Relationship marketing of services - growing interest, emerging perspectives", Journal of the Academy of Marketing Science, vol. 23, no. 4, pp. 236-245.

Bitner, M.J. (1995), "Building service relationships: It's all about promises", Journal of the Academy of Marketing Science, vol. 23, no. 4, pp. 246-251.

Bloemer, J., de Ruyter, K. and Wetzels, M. (1999), "Linking perceived service quality and service loyalty: A multi-dimensional perspective", European Journal of Marketing, vol. 33, no. $11 / 12$, pp. 1082-1106.

Blomqvist, R. Dahl, J. and Haeger, T. (1993), Relationsmarknadsforing. Strategi och metod for servicekonkurren (Relationship Marketing, Strategy and Methods for Service Competition), IHM Forlag. Goteborg, Sweden.

Bollen, K.A. (1989), Structural Equations with Latent Variables, John Wiley \& Sons, New York, NY.

Buttle, F. (1996), "Relationship marketing”, in Buttle, F. (Ed.), Relationship Marketing: Theory and Practice, Paul Chapman, London, pp.1-16.

Calonius, H. (1988), “A buying process model”, Proceedings of the XVII Annual Conference of the European Marketing Academy on Innovative Marketing - A European Perspective, University of Bradford, pp. 86-103.

Carlson, L., Grossbart, S. and Tripp, C. (1990), “An investigation of mothers' communication orientation and patterns", Advances in Consumer Research, vol. 17, no. 1, pp. 840-872.

Chin, W.W., Gopal, A. and Salisbury, W.D. (1997), "Advancing the theory of adaptive structuration: The development of a scale to measure faithfulness of appropriation, Information Systems Research, vol. 8, no. 4, pp. 342-367. 
Christopher, M., Payne, A. and Ballantyne, D. (1991), Relationship Marketing: Bringing Quality, Customer Service and Marketing Together, Butterworth, London.

Churchill, G.A. and Surprenant, C. (1982), "An investigation into the determinants of customer satisfaction", Journal of Marketing Research, vol. 19, no. 4, pp. 491-504.

Crosby, L.A. Evans, K.R. and Cowles, D. (1990), "Relationship quality in services selling: An interpersonal influence perspective", Journal of Marketing, vol. 54, no. 3, pp. 68-81.

Dwyer, F.R. Schurr, P.H. and Oh, S. (1987), "Developing buyer-seller relationship", Journal of Marketing, vol. 51, no. 2, pp. 11-27.

Gronroos, C. (1990), "Relationship approach to the marketing function in service contexts: The marketing and organizational behavior interface", Journal of Business Research, vol. 20, no. 1, pp. 3-12.

Gronroos, C. (1994), "From marketing mix to relationship marketing: Towards a paradigm shift in marketing", Management Decision, vol. 32, no. 2, pp. 4-20.

Gummesson, E. (1987), "The new marketing - developing long-term interactive relationships", Long Range Planning, vol. 20, no. 4, pp. 10-20.

Gummesson, E. (1991), "Marketing revisited: The crucial role of the part-time marketers", European Journal of Marketing, vol. 25, no. 2, pp. 60-67.

Gummesson, E. (1993), Relationsmarknadsforing, Fran 4Ps till 30Rs (Relationship Marketing: From 4Ps to 30Rs), Stockholm University, Sweden.

Gundlach, G. and Murphy, P. (1993), "Ethical and legal foundations of relational marketing exchanges", Journal of Marketing, vol. 57, no. 4, pp. 35-46.

Gundlach, G.T., Achrol, R.S. and Mentzer, J.T. (1995), "The structure of commitment in exchange", Journal of Marketing, vol. 59, no. 1, pp. 78-93.

Hair, J.F. Jr., Anderson, R.E., Tatham, R.L. and Black, W.C. (1998), Multivariate Data Analysis, Prentice-Hall, New Jersey, NJ.

Hodgkinson, G. and Johnson, J. (1994), "Exploring the mental models of competitive strategists: The case of a processual approach", Journal of Management Studies, vol. 31, no. 4, pp. 425-448.

Hofstede, G. (1980), Culture's Consequences: International differences in Work Related Values, Sage, Beverly Hills, CA.

Hofstede, G. and Bond, M.H. (1988), "The Confucius connection: From cultural roots to economic growth", Organizational Dynamics, vol. 16, no. 4, pp. 5-21.

Hofstede, G. (1991), "Management in a multicultural society", Malaysian Management Review, vol. 26, no. 1, pp. 13-33. 
Jackson, B.B. (1985), "Building customer relationships that last", Harvard Business Review, vol. 63 , no. 6 , pp. $120-128$.

Kavali, S. Tzokas, N.X. and Saren, M.J. (1999), "Relationship marketing as an ethical approach: Philosophical and managerial considerations", Management Decision, vol. 37, no. 7, pp. 573-581.

Kiesler, C.A. (1971), The Psychology of Commitment, Academic Press, New York, NY.

Kotler, P. (1992), "Its time for total marketing", Business Week ADVANCED Executive Brief, vol. 2.

Lindgreen, A., Palmer, R. and Vanhamme, J. (2004), "Contemporary marketing practice: Theoretical propositions and practical implications", Marketing Intelligence \& Planning, vol. 22 , no. 6, pp. 673-692.

Markoczy, L. (2000), "National culture and strategic change in belief formation", Journal of International Business Studies, vol. 31, no. 3, pp. 427-442.

Moorman, C., Zaltman, G. and Deshpande, R. (1992), "Relationships between providers and users of market research: The dynamics of trust within and between organizations", Journal of Marketing Research, vol. 29, no. 3, pp. 314-328.

Moorman, C., Deshpande, R. and Zaltman, G. (1993), Relationship Between Providers and Users of Market Research: The role of Personal Trust, Marketing Science Institute, Cambridge, MA.

Morgan, R.M. and Hunt, S.D. (1994), "The commitment-trust theory of relationship marketing”, Journal of Marketing, vol. 58, no. 3, pp. 20-38.

Moschis, G.P. and Moore, R.L. (1979), "Family communication and consumer socialization", Advances in Consumer Research, vol. 6, no. 1, pp. 359-363.

Mowday, R.T, Porter, L.W. and Steers, R.M. (1982), Employee-organization Linkages: The Psychology of Commitment, Absenteeism and Turnover, Academic Press, New York, NY.

Ndubisi, N.O. (2006), "Effect of gender on customer loyalty: A relationship marketing approach", Marketing Intelligence \& Planning, vol. 24, no. 1, pp. 48-61.

Ndubisi, N.O. (2007), "Relationship quality antecedents: The Malaysian retail banking perspective", International Journal of Quality and Reliability Management, vol. 24, no. 8, pp. 829-845.

Ndubisi, N.O. and Tam, Y.L.A. (2007), "Evaluating gender differences in the complaint behaviour of Malaysian consumers", Asian Academy of Management Journal, vol. 12, no 2, pp. 1-13.

Osland, J.S. and Byrd, A. (2000), "Beyond sophisticated stereotyping: Cultural sensemaking in context", Academy of Management Executive, vol. 14, no. 1, pp. 65-79. 
Pearce, W.B. (1974), “Trust in interpersonal relationships”, Speech Monographs, vol. 41, no. 3, pp. 236-244.

Rapp, S. and Collins, T. (1990), The Great Marketing Turnaround, Prentice-Hall, Englewood Cliffs, NJ.

Reichheld, F.E. (1993), "Loyalty-based management”, Harvard Business Review, vol. 71, no. 2, pp. 64-73.

Reichheld, F.E. and Sasser, W.E. Jr. (1990), “Zero defections: Quality comes to service”, Harvard Business Review, vol. 68, no. 5, pp. 105-111.

Rosenberg, L., and Czepiel, J. (1983), "A marketing approach for consumer retention", Journal of Consumer Marketing, vol. 1, no. 2, pp. 45-51.

Rusbult, C.E., Farrell, D., Rogers, D. and Mainous, A.G. (1988), "Impact of exchange variables on exit, voice, loyalty, and neglect: An integrative model of responses to declining job satisfaction", Academy of Management Journal, vol. 31, no. 3, pp. 599-627.

Schurr, P.H. and Ozanne, J.L. (1985), "Influence on exchange processes: Buyers' preconceptions of a seller's trust worthiness and bargaining toughness, Journal of Consumer Research, vol. 11, no. 4, pp. 939-953.

Veloutsou, C., Daskou, S. and Daskou, A. (2004), "Are the determinants of bank loyalty brand specific?” Journal of Financial Services Marketing, vol. 9, no 2, pp. 113-125.

Webster, F.E. Jr. (1992), “The changing role of marketing in the corporations", Journal of Marketing, vol. 56, no. 4, pp. 1-17.

Wilson, D.T. (1995), “An integrated model of buyer-seller relationships”, Journal of the Academy of Marketing Science, vol. 23, no. 4, pp. 335-345.

Wong A. and Sohal, A. (2002), "An examination of the relationship between trust, commitment and relationship quality", International Journal of Retail \& Distribution Management, vol. 30, no. 1, pp. 34-50. 